\title{
Implementation of SPADA in General Civic Education Courses in Developing Student Creativity
}

\author{
Dede Iswandi ${ }^{1, *}$ Dasim Budimansyah ${ }^{2}$, Kokom Komalasari $^{3}$, Susan Fitriasari ${ }^{4}$ \\ 1,2,3,4 Universitas Pendidikan Indonesia \\ ${ }^{*}$ Corresponding author.Email: dedeiswandipkn@upi.edu
}

\begin{abstract}
Creativity is a difficult field of study, which gives rise to different views, the difference lies in the definition of creativity, the criteria for creative behavior, the creative process, the relationship between creativity and intelligence, the characteristics of creative people, the relationship between creativity, and efforts to develop creativity in online learning. Creativity in the online learning system contains content in digital form in various formats that are easy to manage, develop and download with existing technology tools easily and packaged with structures that meet learning standards (flows).
\end{abstract}

Keywords: Civic Education, Creativity, General Courses, Online Learning System.

\section{INTRODUCTION}

The General Course (MKU) is a General Education course at Universities in Indonesia that has undergone seven changes, starting from 1954 to 2003. In 1983 the MKU department had an established status, this was based on the issuance of the Decree of the Minister of Education and Culture No. 0174/0/1983. Management at each university majoring in MKU is under FISIPOL and specifically for IKIP majoring in MKU under FPIPS.

Until 2019 the management of General Courses at the Indonesian Education University, the institutional status changed from being a MKDU department to the Department of General Education under FPIPS. General Courses carrying out a national mission in educating the nation's life through "value based education" need to be implemented by every citizen in society, nation and state as religious, moral, and loving Indonesian people. [1]. Following the above thought, General Courses have an important role to be taught to students as prospective teachers to equip students intellectually (IQ) with emotional skills (EQ) and spiritual skills (SQ), to be part of the development of knowledge.

Since it was implemented at the level of higher education, general subjects have experienced various obstacles and limitations. First, the lack of a number of lecturers and the uneven quality of learning; Second, limited facilities and learning resources; Third, lectures tend to use the face-to-face lecture learning method centered on the lecturer (lecturer oriented), so that lectures become passive, students become easily bored and are not creative. Conventional learning makes students lose motivation in learning, physically students carry out routine attendance in class when following the lecture process to study according to the course schedule. Students as objects, only accept what the lecturer has delivered, so they lose the purpose of learning. Innovations carried out in lecture activities are still lacking, so that they become rigid, less creative, become passive causing the interaction between lecturers and students to be boring, so that students are less motivated to learn.

For the lecture to be achieved, a lecturer must understand the situation of students by interacting between lecturers and students, rebuilding motivation and increasing student creativity in lectures. Creative lecturers can manage and utilize everything available in the learning environment, conduct fun lectures, and motivate students. Lecturers can optimize their creativity in the classroom and outside the classroom, in the learning process in the classroom lecturers must of course innovate using various media to make creative learning products.

In addition to using learning media, lecturers must develop student creativity by using innovative learning methods, this process is certainly a challenge for lecturers, according to [2] Creative teaching is an art. Lecturers need to develop a comprehensive list of skills, which can be adapted and applied in different situations. Developing creativity must be applied with clear ethical guidance and learning expectations [3]. The learning process determines the achievement of learning activities. Several factors influence the success of 
learning such as the use of learning techniques, learning capacity, approach, tendencies, and learning situations.

Online Learning System (SPADA), flexible and distributed distance learning, online learning that provides a fun, easy, paperless and flexible learning experience. Flexibility, as well as facilitating the concept of lifelong learning, has the advantage that it can be widely implemented anywhere and anytime along with the development of paperless technology. This system will still be able to take advantage of the advantages of face-to-face lectures to develop human communication between students, lecturers, and other social environments [4]. The advantages of SPADA are that it contains digital content in various formats that are easy to manage, develop and download with existing technology tools. Packed with a structure that meets the standards (flow) of learning. Provides convenience to be operated by students and lecturers through the available navigation menus. The planned system is directed at creating fun learning through various formats that illustrate the phenomena, concepts and principles contained in each topic of discussion. The problems and challenges of each university in providing General Courses, as well as being able to grow student learning abilities creatively and independently [5]. The use of technology in the learning process can produce scientific creativity such as higher-order thinking (higher thinking processes) absorbing information and concepts (acquisition of concepts) in solving and finding something new, seeking and finding problems (problem finder) seeking answers to problems, to achieve results and enjoy the process [6].

\section{CREATIVE CONCEPTS IN EDUCATION}

Research on creativity, according to [7], since 1950 until now creativity has been developed in four themes, according to their respective focuses. In the 1950s the focus of creativity was on the individual, on genius and talent, and on the personality of the person who created it. Then in 1970 the emphasis on creativity shifted to connect creativity with imagination and the need to provide a stimulus for creativity. During the 1980s the concept of creativity obtained by researchers in studying creativity was environmental and social theory. Therefore researchers began to focus on the creativity of ordinary people in the education system. Creativity is difficult to define because creativity is influenced by brain function, therefore creativity has concepts related to person, process, and result.

In his book Creativity - Theory, History, Practice. [8] tries to define the concept of creativity by writing about all aspects that are captured in his sentence "Creativity is extraordinary, original and fitting, full fill. [9] defined creativity as "Activities imaginative work created to produce original and valuable results". Lucas reflects on the difficulty of finding a definition that does not limit the concept of creativity. He proposes the following definition:

Creativity is a state of mind in which all of our intelligence work together. It involves seeing, thinking, and innovating. Although often found in the creative arts, creativity can be demonstrated in any subject in school or in any aspect of life.

Lucas defines creativity as a "state of mind" that allows all of our intelligence (or we can say competence) to work together, creativity is not only measured by intelligence. Lucas revealed that creativity can be found in everyday life, creativity can be used for good or evil, therefore it is necessary to include ethical aspects in creativity. [10] A good definition of creativity will help us identify what we are talking about, why certain things are clearly creative and others are not. Fisher stated that the creative evolution process consists of generation, variation and originality. To create is to produce something, to be productive in thought, word or deed. But generations are not enough. Variation and differentiation is required.

Characteristics of creative people [10]: they are flexible, connect ideas, are unorthodox, show an aesthetic sense, are curious and curious, see similarities and differences, and they question accepted ways of doing things. Fisher claims that many creative breakthroughs occur through intuitive insight, when problems are viewed intuitively in a new way or from a new perspective. The concept of creativity in education is currently being universalized. Elements of creativity [7]:

1. operating in the economic and political fields,

2. act as an enabling vehicle for the empowerment of individuals in institutions and organizations; and

3. used to develop effective learning.

According to the opinion above that these three elements are necessities of life in a world where success is closely related to the creative application of good ideas, where the application of creativity to knowledge is necessary for economic and political development. The challenge for schools and social institutions is to shift the focus of education to developing a population capable of thinking and taking new initiatives, not just repeating what the previous generation has done. These challenges need to be prepared in the face of a world full of challenges and changes like today [10]. Creativity is very important if new ways to solve problems are found.

The teaching and learning process carried out by all educators, regardless of experience, teaching is to aim at providing creative tasks, need a teaching style related to creativity, maintain self-assessment skills, develop questioning skills to improve student learning and provide time for students to explore ideas -ideas, respond positively to creativity in the learning experience [11]. To improve learning, an educator needs to appreciate critical 
and creative thinking both in terms of teaching and learning methods, besides that critical thinking and creative thinking skills must be seen as a balanced mode of thinking, this is necessary so that students can benefit from both modes. think in their academic as well as their personal lives, and students can have a basis for understanding and exploring alternatives [12].

\section{MOTIVATION}

Motivation (more) according to Bimo Walgito [13] means "to move" or to move. So, motivation is defined as the power contained within the organism that encourages to act or is a driving force. In the language of religion, the term motivation according to Tayar Yusuf is not much different from "intention/intention", (innamal a'malu binniat means that the act depends on the intention), namely the tendency of the heart that encourages someone to take action. Thus it can be understood that the basic understanding of motivation is the internal state of the organism that encourages it to do something.

Which is widely used to describe the term motivation or motive, including needs, urges, wants, and drives. The term motivation is defined as a condition in a person that encourages the individual's desire to carry out certain activities to achieve goals. Someone who has motivation has behavior to achieve certain goals. [14].

Motivation according to Greenberg and Baron is defined as a series of processes that move, direct, and maintain individual behavior to achieve several goals. Mathis and Jackson state that motivation is a goalregulated drive and rarely appears in a vacuum. The terms need, desire, desire, or drive are the same as motive, which is the origin of the word motivation. Understanding motivation is important, because reactions to compensation and other human resource issues are related to motivation [15]. Motivation talks about how to encourage one's work spirit, so that they want to work by optimally providing their abilities and expertise to achieve goals. This stimulus will create an impetus for someone to carry out activities. According to Berelson and Steiner cited by Wahjosumidjo, motivation is a conscious effort to influence one's behavior to lead to the achievement of organizational goals.

According to Terry, motivation is the desire contained in an individual that stimulates to take actions. This understanding concludes that motivation is a stimulus that comes from the individual's desire to act. This motivation departs from the motives that are owned by a person, therefore, in any business, the emergence of motivation is needed. To want to grow, people also need motivation. Understanding motivation is not easy. It is something that exists within a person and is not visible from the outside and is only visible through a person's behavior that can be seen. Its role is very big to support work performance [16].
There are three important elements contained in Mc Donald's statement, namely: 1) Motivation initiates a change in energy in each human being. Although the motivation arises from within humans, its appearance will involve human physical activities; 2) Motivation is characterized by the emergence of a feeling/ feeling, one's affection. In this case, motivation is relevant to psychological, affective and emotional issues that can determine human behavior; and 3) Motivation will be stimulated because of the purpose. So, motivation in this case is actually a response to an action, namely a goal. This goal is needed.

\section{CONCLUSION}

In learning activities, lecturers' creativity is required, especially to increase students' learning motivation. Creativity is part of the state of the soul of a student as a human being. Creative abilities are special talents or talents that are manifest in late age or adulthood. While the creativity of special talents are people who have extraordinary creative talents or talents in certain fields, creativity is related to the discovery of something, about things that produce something new by using something that already exists, creative potential can be recognized through the following characteristics: the following: 1) Have a sufficiently large curiosity; 2) Be open to new experiences; 3) Long-suffering; 4) Have a curiosity to find (research); 5) Tend to prefer heavy (difficult) tasks; 6) Tend to seek broad and satisfactory answers; 7) Have dedication, move and actively carry out their duties; 8) flexible thinking; 9) Responding to questions asked and tend to give more answers; 10) Ability to make analysis and synthesis; 11) Has a fairly good abstract power; and 12) Have a fairly broad reading background [17].

Students and lecturers in developing a creative spirit must always be dynamic in communicating, the curriculum that has been designed not only provides provisions so that students can enjoy their time in lectures, but also develops students' abilities to enjoy their lives in the future by developing creativity. Hurlock, an expert in developmental psychology, stated several reasons for neglecting this creativity, including: 1 . The traditional belief that creativity is usually called "genius", is inherited and nothing can be done to make people creative. 2 . The belief that there are only a few creative people, so scientific research should focus on things that affect the majority of society, 3 . They argue that those who are diligent and capable are those who have high intelligence and drive for achievement, tend to be more successful in life. than those who are creative, 4 . There is a traditional belief that creative people are not according to their gender, 5. Creativity is difficult to study and measure [18]. 


\section{REFERENCES}

[1] U. S. Winataputra dan D. Budimansyah, Pendidikan Kewarganegaraan dalam Perspektif Internasional: Konteks, Teori, dan Profil Pembelajaran. Bandung: Widya Aksara Press, 2011.

[2] M. M. Joubert, The art of creative teaching: NACCCE and beyond. In A. Craft, B. Jeffrey, \& M. Leibling (Eds.), Creativity in education. London: Continuum, 2001.

[3] A. Craft, Creativity in Schools: Tensions and Dilemmas. London: Routledge, 2005.

[4] R. Boelens, B. De Wever, dan M. Voet, "Four key challenges to the design of blended learning: A systematic literature review," Educational Research Review. 2017.

[5] C. Henrie, C., Bodily, R., Manwaring, K., \& Graham, "Exploring intensive longitudinal measures of student engagement in blended learning. The International Review Of Research In Open And Distributed Learning," vol. 16, no. 3, 2015.

[6] D. N. Perkins, Knowledge as design. Lawrence Erlbaum Associates.

[7] M. Craft, A.,Jeffrey, B., \& Leibling, Creativity in Education. London- New York: Continuum.

[8] R. Pope, Crtativity: Theory, history, practice. New York: Routledge, 2005.

[9] B. Lucas, "Creative teaching, teaching creativity and creative learning," Creat. Educ., hal. 35-44, Jan 2001.

[10] R. Fisher dan M. Williams, Unlocking creativty: teaching across the curriculum. London: David Fulton Publishers Ltd, 2004.

[11] S. Turner, "Teachers' and pupils' perceptions of creativity across different key stages," Res. Educ., vol. 89, no. 1, hal. 23-40, 2013.

[12] K. C. Tsai, "Being a Critical and Creative Thinker: A Balanced Thinking Mode," Asian J. Humanit. Soc. Sci., vol. 1, no. 2, hal. 1-9, 2013.

[13] Abas Erjati, Magnet Kepemimpinan Kepala Madrasah Terhadap Kinerja Guru. Jakarta: Elex Media Komputindo, 2017.

[14] Handoko Hani T, Manajemen. Yogyakarta: BPFE, 2009.

[15] Sunyoto Danang dan Burhanudin, Perilaku Organisasional. Jakarta: CAPS, 2011.

[16] Sunhaji, Manajemen Madrasah. Yogyakarta: Grafindo \& Purwokerto. STAIN Press.

[17] Slameto, Belajar dan Faktor-faktor yang mempengaruhinya. Jakarta: Rineka Cipta, 2010.

[18] E. . Hurlock, Psikologi Perkembangan, 5th editio. Jakarta: Erlanga. 